Check for updates

Cite this: RSC Adv., 2017, 7, 47709

Received 17th September 2017 Accepted 5th October 2017

DOI: $10.1039 / c 7 r a 10326 c$

rsc.li/rsc-advances

\section{Pillar[5]arene-based fluorescent polymer for selective detection and removal of mercury ions $\uparrow$}

\author{
Jin-Fa Chen, Bing-Bing Han, Jin-Feng Ma, Xi Liu, Qing-Yu Yang, Qi Lin, (D) * Hong Yao, \\ You-Ming Zhang (iD) and Tai-Bao Wei (iD *
}

A novel pillar[5]arene-based thioacetohydrazone functionalized fluorescent polymer was designed and synthesized. This polymer not only contains pillar[5]arene units as the fluorophore (signal transducer) but also embedded the thioacetohydrazone group as the ionophore (cation receptor). Therefore, it displays specificity response for mercury ion over other common cations $\left(\mathrm{Mg}^{2+}, \mathrm{Ca}^{2+}, \mathrm{Zn}^{2+}, \mathrm{Co}^{2+}, \mathrm{Fe}^{3+}, \mathrm{Pb}^{2+}\right.$, $\mathrm{Cd}^{2+}, \mathrm{Ni}^{2+}, \mathrm{Tb}^{3+}, \mathrm{Cu}^{2+}, \mathrm{Eu}^{3+}, \mathrm{Fe}^{2+}, \mathrm{Cr}^{3+}, \mathrm{Ag}^{+}$and $\left.\mathrm{La}^{3+}\right)$ in $\mathrm{DMSO} / \mathrm{H}_{2} \mathrm{O}(1: 1, \mathrm{v} / \mathrm{v})$. Competitive cations did not show any significant changes in emission intensity and the fluorescence spectra detection limit was $8.12 \times 10^{-7} \mathrm{M}$, indicating the high selectivity and sensitivity of the polymer towards $\mathrm{Hg}^{2+}$. Meanwhile, this polymer can efficiently remove $\mathrm{Hg}^{2+}$ from water.

\section{Introduction}

Because of their high toxicity and bioaccumulation, heavy metal ions released into the environment can lead to a wide range of severe diseases. ${ }^{\mathbf{1}}$ Considerable efforts are accordingly being devoted to developing new methodologies for detection and removal of specific toxic metal ions. ${ }^{2}$ For example, many types of small molecules have been designed as fluorescent sensors for selective and sensitive detection of metal ions. ${ }^{3}$ On the other hand, various absorbents, such as porous silicas, ${ }^{4}$ hydrogels, ${ }^{5}$ nanoparticles, ${ }^{6}$ and metal-organic frameworks (MOFs), ${ }^{7}$ are being tested for the possible removal of toxic ions. However, most of the developed methods can only perform either the detection or the removal tasks separately, which limits their practical applications.

Pillararenes, a new kind of macrocyclic compounds, are composed of hydroquinone units linked by methylene bridges at the para positions. ${ }^{8}$ They have novel host-guest binding properties due to being easier to functionalize by different substituents on the benzene rings, ${ }^{9}$ thus functionalized pillararenes attracted a lot of attention of scientists. ${ }^{\mathbf{1 0}}$ Since it has multiple benzene ring units, it has a certain luminescent properties. ${ }^{11}$ Therefore, pillararenes are used for fluorescence detection of ions, ${ }^{12}$ but most of them are used to identify iron ions. ${ }^{13}$ In addition, these reports rarely mentioned the corresponding ion can be removed. In order to extend the application

Key Laboratory of Eco-Environment-Related Polymer Materials, Ministry of Education of China, Key Laboratory of Polymer Materials of Gansu Province, College of Chemistry and Chemical Engineering, Northwest Normal University, Lanzhou, Gansu, 730070, P. R. China. E-mail: weitaibao@126.com; linqi2004@126.com; Fax: +86 9317973191; Tel: +869317973191

$\dagger$ Electronic supplementary information (ESI) available: ${ }^{1} \mathrm{H}$ NMR date and other materials. See DOI: 10.1039/c7ra10326c of pillararenes, it is quite necessary to design and synthesize novel pillararenes for detection and removal of ions.

Polymers have been widely used as organic light-emitting diodes (OLEDs), ${ }^{\mathbf{1 4}}$ thin-film transistors, chemical sensors, ${ }^{\mathbf{1 5}}$ and in various photonic and electronic devices. ${ }^{16}$ However, the pillar[5] arene-based polymer have rarely been reported. ${ }^{17}$ On the other hand, the use of pillar[5]arene-based polymers to detect and remove ions hasn't been reported.

Herein, we designed and synthesized a pillar[5]arene-based fluorescent polymer for detecting and removing the metal ions. As a proof-of-concept, a thioacetohydrazone functionalized fluorescent polymer, PP5, was designed and applied for the selective sensing and effective removal of the toxic $\mathrm{Hg}^{2+}$ (Scheme 1). Although we have previously studied the selective detection and removal of mercury ions, these sensors are small molecules. ${ }^{18}$ However, this report is the use of pillar[5]arenebased polymer for the selective detection and removal of mercury ions. Although it has previously been reported that the

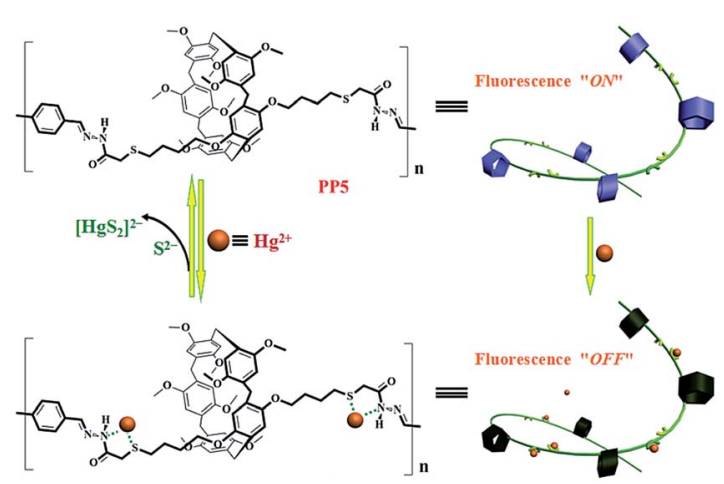

Scheme 1 The pillar[5]arene-based polymer PP5 was applied for both fluorescent detection and removal of $\mathrm{Hg}^{2+}$. 
use of pillar[5]arene-based pseudorotaxane to detect and remove mercury ions, it is the host-guest complex (no polymer). Importantly, the real-time fluorescence response did show efficient quenching of PP5 upon the addition of $\mathrm{Hg}^{2+}$. Excellent sensitivity and selectivity toward the $\mathrm{Hg}^{2+}$ detection were verified in the presence of other competitive cations. The removal ability of PP5 was further elucidated by the effective separation of $\mathrm{Hg}^{2+}$ from water. Meanwhile, PP5 can recycle detection and removal of $\mathrm{Hg}^{2+}$.

\section{Experimental}

\section{Materials and instruments}

1,4-Dimethoxybenzene, boron trifluoride ethyl ether complex, 1,4-dibromobutane and ethyl mercaptoacetate were reagent grade and used as received. Solvents were either employed as purchased or dried by $\mathrm{CaCl}_{2} \cdot{ }^{1} \mathrm{H}$ NMR spectra were recorded on a Mercury-600BB spectrometer at $600 \mathrm{MHz}$ and ${ }^{13} \mathrm{C} \mathrm{NMR}$ spectra were recorded on a Mercury-600BB spectrometer at $151 \mathrm{MHz}$. Chemical shifts are reported in ppm downfield from tetramethylsilane (TMS, $\delta$ scale with solvent resonances as internal standards). Melting points were measured on an X-4 digital melting-point apparatus (uncorrected). Mass spectra were performed on a Bruker Esquire 3000 plus mass spectrometer (Bruker-FranzenAnalytik GmbH Bremen, Germany) equipped with ESI interface and ion trap analyzer. The morphologies and sizes of the polymer were characterized using field emission scanning electron microscopy (FE-SEM, JSM$6701 \mathrm{~F}$ ) at an accelerating voltage of $8 \mathrm{kV}$. The X-ray diffraction analysis (XRD) was performed in a transmission mode with a Rigaku RINT2000 diffractometer equipped with graphite monochromated CuK $\alpha$ radiation $(\lambda=1.54073 \AA)$. The infrared spectra were performed on a Digilab FTS-3000 Fourier transforminfrared spectrophotometer. Fluorescence spectra were recorded on a Shimadzu RF-5301PC spectrofluorophotometer.

\section{Adsorption experiments}

The adsorption experiments were performed at different mercury(II) concentration, corresponding adsorbent and room temperature (Table $\mathrm{S} 1 \dagger$ ). The experiments were carried out in $25 \mathrm{~mL}$ round-bottom flasks, with continuously stirring (usually for $5 \mathrm{~h}$ ). The residual concentration of mercury(II) was determined by the inductively coupled plasma (ICP) analysis.

\section{Synthetic procedures}

Synthesis of 1,4-bis(4-bromobutoxy)benzene 1. Hydroquinone (2.3 g, $20.0 \mathrm{mmol}), \mathrm{K}_{2} \mathrm{CO}_{3}(16.6 \mathrm{~g}, 120 \mathrm{mmol})$, KI (6.6 g, $40 \mathrm{mmol}), 1$,4-dibromobutane $(34.6 \mathrm{~g}, 160 \mathrm{mmol})$ and acetone $(400.0 \mathrm{~mL})$ were added in a $500 \mathrm{~mL}$ round-bottom flask stirred at room temperature. The reaction mixture was stirred at reflux for 1.5 days. After the solid was filtered off, the solvent was evaporated and the residue was dissolved in $\mathrm{CH}_{2} \mathrm{Cl}_{2}$. Column chromatography (silica gel; petroleum ether : $\mathrm{CH}_{2} \mathrm{Cl}_{2}=10: 1$ ) afforded a white solid (6.0 g, 80\%). Mp 83-85 ${ }^{\circ} \mathrm{C} .{ }^{1} \mathrm{H}$ NMR $\left(600 \mathrm{MHz}, \mathrm{CDCl}_{3}\right) \delta 6.83(\mathrm{~d}, J=0.8 \mathrm{~Hz}, 4 \mathrm{H}), 3.96(\mathrm{t}, J=6.0 \mathrm{~Hz}$, $4 \mathrm{H}), 3.52-3.25(\mathrm{~m}, 4 \mathrm{H}), 2.10-1.88(\mathrm{~m}, 8 \mathrm{H})$.
Synthesis of a copillar[5] arene 2. To a solution of 1,4-bis(4bromobutoxy)benzene $(1.90 \mathrm{~g}, 5.0 \mathrm{mmol})$ and 1,4-dimethoxybenzene $(2.76 \mathrm{~g}, 20.0 \mathrm{mmol})$ in 1,2-dichloroethane $(200 \mathrm{~mL})$, paraformaldehyde $(0.75 \mathrm{~g}, 25.0 \mathrm{mmol})$ was added under nitrogen atmosphere. Then boron trifluoride diethyl etherate (6.75 $\mathrm{mL}, 25 \mathrm{mmol}$ ) was added to the solution and the mixture was stirred at room temperature for $4 \mathrm{~h}$ and concentrated by rotary evaporation. The resultant oil was dissolved in $\mathrm{CH}_{2} \mathrm{Cl}_{2}$ and washed twice with $\mathrm{H}_{2} \mathrm{O}$. The organic layer was dried over anhydrous $\mathrm{Na}_{2} \mathrm{SO}_{4}$ and evaporated to afford the crude product, which was isolated by flash column chromatography using petroleum ether/ethyl acetate $(20: 1, \mathrm{v} / \mathrm{v})$ to give $2(1.69 \mathrm{~g}, 34 \%)$ as a white solid. Mp 187-189 ${ }^{\circ} \mathrm{C} .{ }^{1} \mathrm{H}$ NMR (600 MHz, $\mathrm{CDCl}_{3}$ ) $\delta$ 6.84-6.74 (m, 10H), $3.87(\mathrm{t}, J=5.9 \mathrm{~Hz}, 4 \mathrm{H}), 3.83-3.78(\mathrm{~m}, 10 \mathrm{H})$, $3.72(\mathrm{t}, J=19.9 \mathrm{~Hz}, 24 \mathrm{H}), 3.33(\mathrm{~s}, 4 \mathrm{H}), 1.94(\mathrm{~s}, 4 \mathrm{H}), 1.84(\mathrm{~s}, 4 \mathrm{H})$. ${ }^{13} \mathrm{C}$ NMR (151 MHz, $\mathrm{CDCl}_{3}$ ) $\delta 150.80(\mathrm{~s}), 150.75$ (s), $150.70(\mathrm{~s})$, 150.58 (s), 149.84 (s), 128.44 (s), 128.30 (s), 128.08 (s), 114.89 (s), 114.15 (s), 113.92 (s), 113.71 (s), 67.32 (s), 55.95 (d, $J=3.6 \mathrm{~Hz}$ ), 55.76 (s), 55.70 (s), 33.34 (s), 30.55 (s), 29.75 (s), 29.48 (d, J = 5.2 $\mathrm{Hz}), 29.19(\mathrm{~s}), 28.32(\mathrm{~s})$. ESI-MS $m / z:\left(\mathrm{M}+\mathrm{NH}_{4}\right)^{+}$calcd for $\mathrm{C}_{51} \mathrm{H}_{64} \mathrm{O}_{10} \mathrm{Br}_{2} \mathrm{~N}$ 1010.2871; found 1010.2878.

Synthesis of functionalized pillar[5]arene 3. Copillar[5]arene $2(0.5 \mathrm{~g}, 0.5 \mathrm{mmol}) \mathrm{K}_{2} \mathrm{CO}_{3}(0.28 \mathrm{~g}, 2 \mathrm{mmol})$ and ethyl mercaptoacetate $(0.3 \mathrm{~mL}, 2.75 \mathrm{mmol})$ were added to acetone $(80 \mathrm{~mL})$. The solution was refluxed overnight. After the solid was filtered off, the solvent was evaporated and the residue was dissolved in $\mathrm{CH}_{2} \mathrm{Cl}_{2}$. Column chromatography (silica gel; petroleum ether : $\left.\mathrm{CH}_{2} \mathrm{Cl}_{2}=20: 1\right)$ afforded a white solid $(6.0 \mathrm{~g}, 80 \%) .{ }^{1} \mathrm{H}$ NMR (600 MHz, $\left.\mathrm{CDCl}_{3}\right) \delta 6.78(\mathrm{dd}, J=14.3,7.1 \mathrm{~Hz}, 10 \mathrm{H}), 3.85(\mathrm{t}$, $J=5.8 \mathrm{~Hz}, 4 \mathrm{H}), 3.79-3.74(\mathrm{~m}, 14 \mathrm{H}), 3.71(\mathrm{~s}, 6 \mathrm{H}), 3.69(\mathrm{~s}, 12 \mathrm{H})$, $3.66(\mathrm{~s}, 12 \mathrm{H}), 3.24(\mathrm{~s}, 4 \mathrm{H}), 2.72(\mathrm{t}, J=7.0 \mathrm{~Hz}, 4 \mathrm{H}), 1.87$ (ddd, $J=$ 26.5, 14.7, $7.9 \mathrm{~Hz}, 8 \mathrm{H}) .{ }^{13} \mathrm{C}$ NMR $\left(151 \mathrm{MHz}, \mathrm{CDCl}_{3}\right) \delta 170.88(\mathrm{~s})$, 151.71-148.89 (m), 129.38-126.85 (m), 116.55-112.46 (m), 67.71 (s), 55.73 (dd, $J=10.4,5.9 \mathrm{~Hz}), 52.34$ (s), 41.19 (s), 33.42 (s), 32.52 (s), 29.46 (s), 28.86 (s), 25.72 (s).

Synthesis of pillar[5] arene 4. Functionalized pillar[5]arene 3 $(0.5 \mathrm{~g}, 0.5 \mathrm{mmol})$ and hydrazine hydrate $(0.3 \mathrm{~mL}, 6 \mathrm{mmol})$ were added to ethanol $(20 \mathrm{~mL})$. The solution was refluxed overnight. Then the solvent was removed by evaporation, you can afford a white solid. After white solid was washed by ethanol to obtain 4 as a white solid (0.48 g, 93\%). ${ }^{1} \mathrm{H}$ NMR (600 MHz, DMSO- $d_{6}$ ) $\delta 9.11(\mathrm{~s}, 2 \mathrm{H}), 6.78(\mathrm{~d}, J=3.4 \mathrm{~Hz}, 10 \mathrm{H}), 4.34(\mathrm{~s}, 4 \mathrm{H}), 3.84(\mathrm{~s}, 4 \mathrm{H})$, 3.75-3.61 (m, 34H), 3.06 (s, 4H), 2.67 (s, 4H), 1.80 (dd, $J=29.0$, $7.3 \mathrm{~Hz}, 8 \mathrm{H}) .{ }^{13} \mathrm{C}$ NMR (151 MHz, DMSO- $\left.d_{6}\right) \delta 168.92(\mathrm{~s}), 150.32$ (s), 127.90 (s), 113.69 (s), 67.84 (s), 55.89 (s), 32.99 (s), 32.09 (s), $29.42(\mathrm{~s}), 28.80(\mathrm{~s}), 25.96(\mathrm{~s})$. ESI-MS $m / z:(\mathrm{M}+\mathrm{H})^{+}$calcd for $\mathrm{C}_{55} \mathrm{H}_{71} \mathrm{O}_{12} \mathrm{~N}_{4} \mathrm{~S}_{2}$ 1043.44; found 1043.2296.

Synthesis of polymer PP5. To a solution of pillar[5] arene 4 $(0.21 \mathrm{~g}, 0.2 \mathrm{mmol})$ in ethanol $(20 \mathrm{~mL})$, terephthalaldehyde $(0.027 \mathrm{~g}, 0.2 \mathrm{mmol})$ and acetic acid $(0.05 \mathrm{mmol}$, as a catalyst) was added at room temperature. The mixture was refluxed for $48 \mathrm{~h}$, and yellow solids were precipitated. The solid was isolated by sucking filtration, washed with $\mathrm{MeOH}$, dried at $80{ }^{\circ} \mathrm{C}$ under vacuum for $12 \mathrm{~h}$ to yield PP5 as a yellow powder $(0.18 \mathrm{~g}, 75 \%$ yield). IR (powder, $\left.\mathrm{KBr}, \mathrm{cm}^{-1}\right) 3217(\mathrm{~N}-\mathrm{H}), 1679(\mathrm{C}=\mathrm{O}), 1620$ $(\mathrm{C}=\mathrm{N}), 834(\mathrm{Ar}-\mathrm{H})$. 
Synthesis of the model compound M1. To a solution of pillar [5]arene $4(0.21 \mathrm{~g}, 0.2 \mathrm{mmol})$ in ethanol $(20 \mathrm{~mL})$, benzaldehyde $(45 \mu \mathrm{L}, 0.44 \mathrm{mmol})$ and acetic acid $(0.05 \mathrm{mmol}$, as a catalyst) was added at room temperature. The mixture was refluxed for $48 \mathrm{~h}$, and white powder were precipitated. The solid was isolated by sucking filtration, washed with $\mathrm{MeOH}$, dried at $80{ }^{\circ} \mathrm{C}$ under vacuum for $12 \mathrm{~h}$ to yield $\mathbf{M 1}$ as a white powder $(0.21 \mathrm{~g}, 85 \%$ yield). ${ }^{1} \mathrm{H}$ NMR (600 MHz, DMSO- $\left.d_{6}\right) \delta 11.47$ (s, 1H), 11.37 (s, 1H), $8.18(\mathrm{~s}, 1 \mathrm{H}), 7.97(\mathrm{~s}, 1 \mathrm{H}), 7.65(\mathrm{dd}, J=17.4,6.0 \mathrm{~Hz}, 4 \mathrm{H})$, 7.49-7.26 (m, 6H), 6.75 (s, 10H), $3.81(\mathrm{~s}, 4 \mathrm{H}), 3.63(\mathrm{~s}, 34 \mathrm{H}), 3.29$ (s, 4H), $2.71(\mathrm{~d}, J=5.7 \mathrm{~Hz}, 4 \mathrm{H}), 1.80(\mathrm{~s}, 8 \mathrm{H})$.

\section{Results and discussion}

The polymer PP5 shown in Scheme 1 and the synthesis details are presented in Scheme $\mathrm{S} 1 . \dagger$ The model compound M1 (as a soluble-molecule counterpart of PP5, structure shown in Scheme S2 $\dagger$ ) also been synthesized. Their intermediate and the model compound M1 have been characterized by ${ }^{1} \mathrm{H} \mathrm{NMR},{ }^{13} \mathrm{C}$ NMR, and ESI-MS (Fig. S1-S11 $\dagger$ ). This polymer not only contains pillar[5]arene units as the fluorophore (signal transducer) but also embedded the thioacetohydrazone group as the ionophore (cation receptor). These unique characteristics are expected to be beneficial for the performance in selective detection and facile removal of $\mathrm{Hg}^{2+}$. PP5 also been characterized by IR (Fig. S10†).

With the robust hydrazone linkage in its structure, PP5 is insoluble and stable in common organic solvents, such as DMF, THF, DMSO, acetone, acetonitrile, ethanol and $\mathrm{CHCl}_{3}$. Importantly, PP5 is also insoluble and very stable in water. Thermogravimetric analysis (TGA) indicates that PP5 is thermally stable up to $285{ }^{\circ} \mathrm{C}$ (Fig. S12 $\dagger$ ). The scanning electron microscopy (SEM) images showed that PP5 possessed the irregular granular morphology (Fig. S13 $\dagger$ ). A characteristic vibrational band appeared at $1620 \mathrm{~cm}^{-1}$ in the FT-IR spectrum of PP5 (Fig. S10†), indicating the successful condensation of 1,4phthalaldehyde and $\mathbf{4}$ via the formation of $-\mathrm{C}=\mathrm{N}-$ bonds. Meanwhile, we also investigated the crystallinity of this polymer in the solid state using powder XRD measurements (Fig. S14 $\dagger$ ). However, the peak of the polymer is the bread peak and significantly lower than compound 4, which indicates that PP5 is amorphous.

In order to investigate the luminescence properties of PP5, the insoluble polymer PP5 be dispersed in $\mathrm{DMSO} / \mathrm{H}_{2} \mathrm{O}(1: 1$, $\mathrm{v} / \mathrm{v}$ ), and a series of host-guest recognition experiments were carried out. PP5 toward various cations (including $\mathrm{Mg}^{2+}, \mathrm{Ca}^{2+}$, $\mathrm{Zn}^{2+}, \mathrm{Co}^{2+}, \mathrm{Fe}^{3+}, \mathrm{Pb}^{2+}, \mathrm{Hg}^{2+}, \mathrm{Cd}^{2+}, \mathrm{Ni}^{2+}, \mathrm{Tb}^{3+}, \mathrm{Cu}^{2+}, \mathrm{Eu}^{3+}, \mathrm{Fe}^{2+}$, $\mathrm{Cr}^{3+}, \mathrm{Ag}^{+}$and $\mathrm{La}^{3+}$ ) were primarily investigated using fluorescence spectroscopy. In the fluorescence spectrum, the maximum emission of PP5 appeared at $470 \mathrm{~nm}$ while excited at $\lambda_{\text {ex }}=340 \mathrm{~nm}$ in DMSO/ $\mathrm{H}_{2} \mathrm{O}(1: 1, \mathrm{v} / \mathrm{v})$. When 10.0 equiv. of $\mathrm{Hg}^{2+}$ was added to the dispersed solution of PP5, the fluorescence emission band was quenched (Fig. S15 $\dagger$ ). The same tests were applied using $\mathrm{Mg}^{2+}, \mathrm{Ca}^{2+}, \mathrm{Zn}^{2+}, \mathrm{Co}^{2+}, \mathrm{Fe}^{3+}, \mathrm{Pb}^{2+}, \mathrm{Cd}^{2+}, \mathrm{Ni}^{2+}, \mathrm{Tb}^{3+}$, $\mathrm{Cu}^{2+}, \mathrm{Eu}^{3+}, \mathrm{Fe}^{2+}, \mathrm{Cr}^{3+}, \mathrm{Ag}^{+}$and $\mathrm{La}^{3+}$ cations, and only $\mathrm{Hg}^{2+}$ have significant changes in the fluorescence spectrum, and none of those other cations induced any significant changes in the fluorescent spectrum (Fig. 1).

To further exploit the utility of the polymer PP5 as cation selective sensor for $\mathrm{Hg}^{2+}$, competitive experiments were carried out in the presence of 10.0 equiv. of $\mathrm{Hg}^{2+}$ and 10.0 equiv. of various cations in $\mathrm{DMSO} / \mathrm{H}_{2} \mathrm{O}(1: 1, \mathrm{v} / \mathrm{v})$. The fluorescence selectivity was examined at an emission wavelength of $470 \mathrm{~nm}$, neither of the competitive metal ions showed an appreciable influence on the $\mathrm{Hg}^{2+}$ detection (Fig. 2). These results further identified that PP5 exhibits a satisfactory selectivity toward $\mathrm{Hg}^{2+}$ detection.

The sensitivity of PP5 toward the $\mathrm{Hg}^{2+}$ detection was evaluated via the real-time fluorescence response. For this purpose, the stock solution of $\mathrm{Hg}\left(\mathrm{ClO}_{4}\right)_{2}$ was gradually added to the suspension of PP5 in DMSO/ $\mathrm{H}_{2} \mathrm{O}(1: 1, \mathrm{v} / \mathrm{v})$, and the corresponding fluorescence spectra were measured immediately (Fig. 3). The detection limit of the fluorescent spectrum changes calculated on the basis of $3 \delta / \mathrm{S}$ is $8.12 \times 10^{-7} \mathrm{~mol} \mathrm{~L}^{-1}$ (Fig. S16 $\dagger$ ), indicating the high sensitivity of the sensor to $\mathrm{Hg}^{2+}$.

To further illustrate the effective removal of $\mathrm{Hg}^{2+}$ from water, PP5 (8 mg) was suspended in a dilute aqueous solution of $\mathrm{Hg}\left(\mathrm{ClO}_{4}\right)_{2}(100 \mathrm{ppm}$ in $10.0 \mathrm{~mL})$. After the mixture was stirred at room temperature for $5 \mathrm{~h}$. The inductively coupled plasma (ICP) analysis verified that the concentration of the residual $\mathrm{Hg}^{2+}$ in

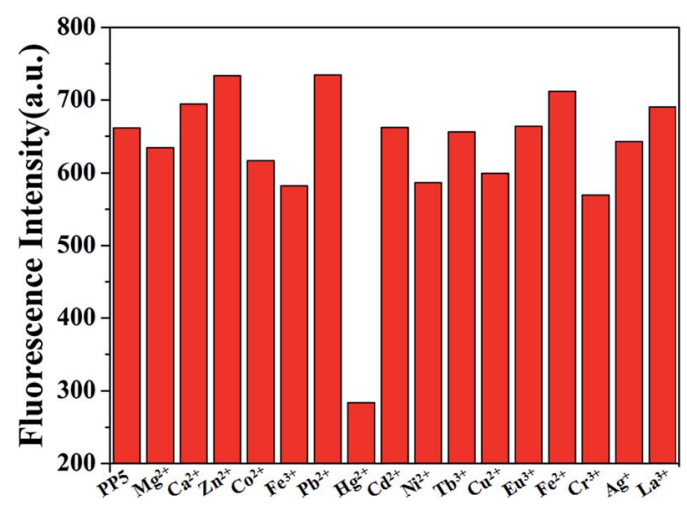

Fig. 1 Fluorescence spectra responses for PP5 ([RU] $\left.=4 \times 10^{-5} \mathrm{M}\right)$ and each of the various cations $\left(4 \times 10^{-4} \mathrm{M}\right)$ in $\mathrm{DMSO} / \mathrm{H}_{2} \mathrm{O}(1: 1, \mathrm{v} / \mathrm{v})$.

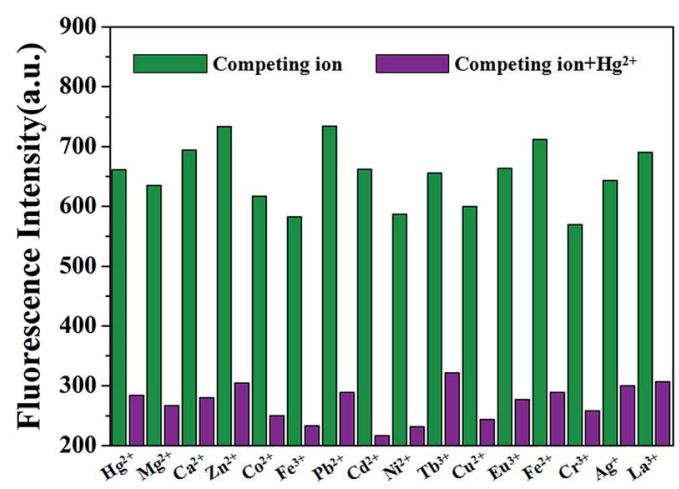

Fig. 2 Fluorescence of PP5 ([RU] $\left.=4 \times 10^{-5} \mathrm{M}\right)$ at $470 \mathrm{~nm}$ with addition of 10.0 equiv. of $\mathrm{Hg}^{2+}$ in the presence of 10.0 equiv. of other cations in $\mathrm{DMSO} / \mathrm{H}_{2} \mathrm{O}(1: 1, \mathrm{v} / \mathrm{v})$. 


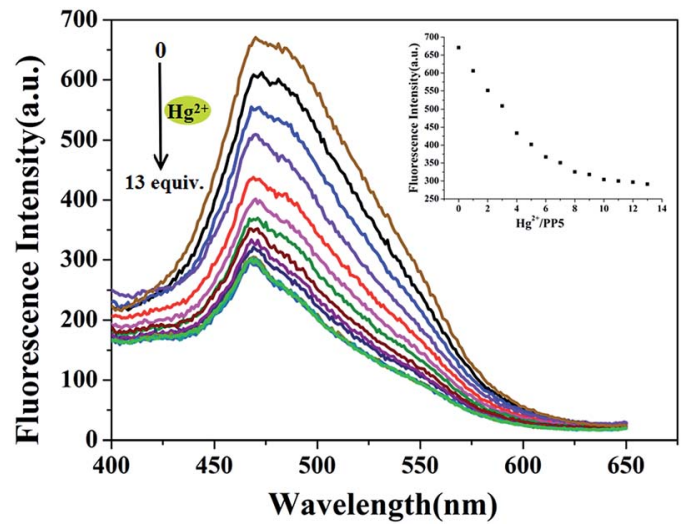

Fig. 3 Fluorescence spectra of PP5 ([RU] $\left.=4 \times 10^{-5} \mathrm{M}\right)$ in the presence of different concentration of $\mathrm{Hg}^{2+}$ in DMSO/ $\mathrm{H}_{2} \mathrm{O}(1: 1, \mathrm{v} / \mathrm{v})$. Inset: A plot of emission at $470 \mathrm{~nm}$ versus number of equivalents of $\mathrm{Hg}^{2+}$.

water was $3.75 \mathrm{ppm}$, that is, $96.25 \%$ of the mercury was removed by polymer PP5. Therefore, this polymer could effectively remove $\mathrm{Hg}^{2+}$ from water. In addition, the adsorption capacity of adsorbent have been calculated by the adsorption experiment data (Table $\mathrm{S} 1 \dagger$ ). The average value of adsorption capacity is $108 \mathrm{mg} \mathrm{g}^{-1}$ at room temperature.

On the basis of the excellent $\mathrm{Hg}^{2+}$ uptake capacity, we further explored the recycle use of PP5. Upon the simple treatment with 5 equiv. of aqueous $\mathrm{Na}_{2} \mathrm{~S}$ solution to exchange the adsorbed $\mathrm{Hg}^{2+}$ out, ${ }^{19}$ the fluorescence of PP5 could be easily recovered. As shown in Fig. 4, this $\mathrm{Hg}^{2+}$ adsorption-desorption cycle could be repeated at least four times without significant loss of the sensitivity and responsiveness of PP5.

We used model compound M1 to study the possible mechanism by ${ }^{1} \mathrm{H}$ NMR titration experiments because PP5 is difficult to be dissolved. Partial proton NMR spectra of M1 is shown in Fig. 5(a), and the signal assignments are depicted on the top. Upon the adsorption of $\mathrm{Hg}^{2+}, \mathrm{H}_{1}$ and $\mathrm{H}_{3}$ signals of $\mathbf{M 1}$ showed a obvious downfield shift (Fig. 5(b)). This result identified $\mathrm{Hg}^{2+}$ have the strong interaction with $\mathrm{S}$ and $\mathrm{N}$ atoms in $\mathrm{Hg} / \mathbf{M} 1$.

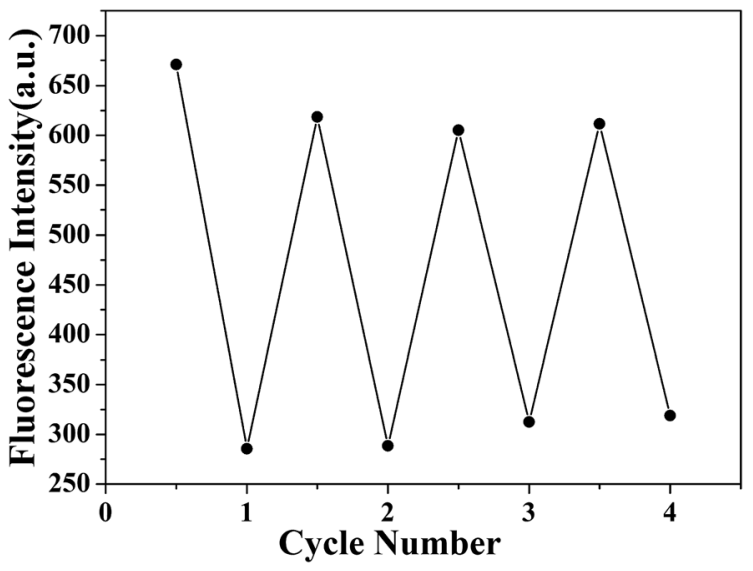

Fig. 4 Recycle use of PP5 for selective detection and facile removal of the toxic $\mathrm{Hg}^{2+}$. Upon treatment in aqueous $\mathrm{Na}_{2} \mathrm{~S}$ solution, PP5 was easily recovered and could be repeatedly used.

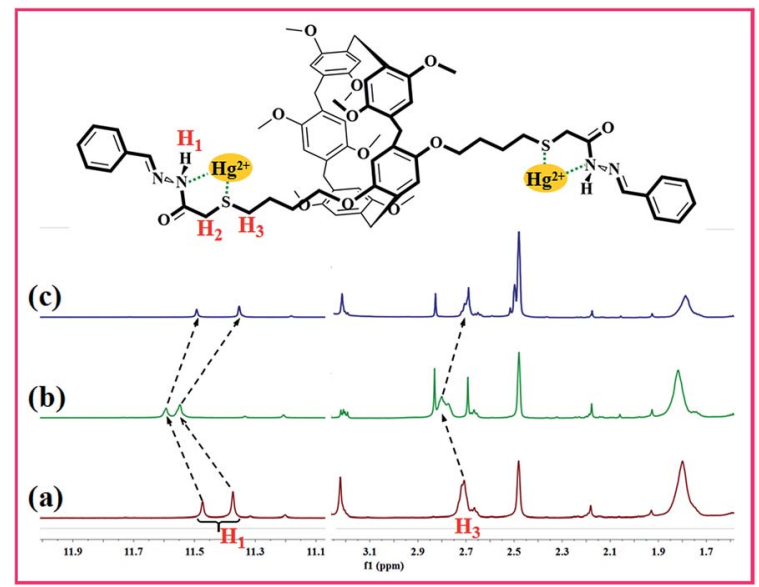

Fig. $5{ }^{1} \mathrm{H}$ NMR spectra of M1 (a), Hg/M1 (b), and Hg/M1 after the treatment with $\mathrm{Na}_{2} \mathrm{~S}$ (c). $\mathrm{H}_{1}$ and $\mathrm{H}_{3}$ signals of $\mathrm{M} 1$ was downfield shifted, which verified that mercury ions have a stronger coordination ability with $\mathrm{S}$ and $\mathrm{N}$ atoms.

Meanwhile, after the treatment of $\mathrm{Hg} / \mathbf{M 1}$ with $\mathrm{Na}_{2} \mathrm{~S}$, the ${ }^{1} \mathrm{H}$ NMR spectrum recorded thereafter (Fig. 5(c)) closely resembles that of fresh M1. The results also illustrate the formation of complexes $\left[\mathrm{HgS}_{2}\right]^{2-}$. Therefore, the selective detection and effective removal of $\mathrm{Hg}^{2+}$ for PP5 stems indeed from $\mathrm{Hg}^{2+}$ have the strong interaction with $\mathrm{S}$ and $\mathrm{N}$ atoms.

The recognition mechanism of the polymer PP5 with $\mathrm{Hg}^{2+}$ was also investigated by IR spectroscopy. In the IR spectrum of PP5 (Fig. 6), the $\mathrm{N}-\mathrm{H}$ bond show the stretching vibrations absorption peak at $3217 \mathrm{~cm}^{-1}$. However, after the addition of $\mathrm{Hg}^{2+}$, this peak shifts to $3448 \mathrm{~cm}^{-1}$. Meanwhile, the $\nu_{\mathrm{C}-\mathrm{S}-\mathrm{C}}$ band at $955 \mathrm{~cm}^{-1}$ was also changed, which indicates that PP5 bonds to $\mathrm{Hg}^{2+}$ via $\mathrm{S}$ and $\mathrm{N}$ atoms. In addition, the $\nu_{\mathrm{C}=\mathrm{O}}$ band at $1679 \mathrm{~cm}^{-1}$ and the $\nu_{\mathrm{C}=\mathrm{N}}$ band at $1620 \mathrm{~cm}^{-1}$ were almost unchanged, implying that $\mathrm{Hg}^{2+}$ does not bind to the $-\mathrm{C}=\mathrm{O}$ bonds and $-\mathrm{C}=\mathrm{N}$ bonds (instead, to the $\mathrm{S}$ atoms and the $\mathrm{N}$ atom of $\mathrm{N}-\mathrm{H}$ groups) in PP5. According to powder XRD measurements (Fig. S14 $\dagger$ ), no clear new peaks were detected when mercury ions are added to the polymer PP5, indicating

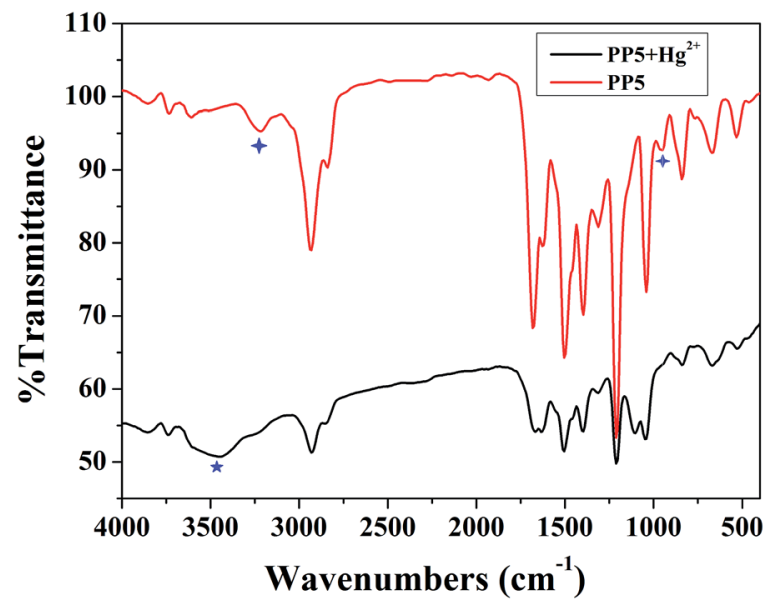

Fig. 6 IR spectra of PP5 (red) and PP5 $-\mathrm{Hg}^{2+}$ (black) in $\mathrm{KBr}$ disks. 
that the amorphous of the polymer is not destroyed. Therefore, the mercury ions should be coordinated with $\mathrm{S}$ and $\mathrm{N}$ atoms.

\section{Conclusions}

In summary, a novel pillar[5]arene-based thioacetohydrazone functionalized fluorescent polymer has been synthesized, and it is used for fluorescence detection and removal of the toxic mercury ions. Meanwhile, this polymer exhibits high selectivity and sensitivity $\left(8.12 \times 10^{-7} \mathrm{M}\right)$, and it can the efficient removal of $\mathrm{Hg}^{2+}$ from water. This research not only explored a new method for the synthesis of pillararene-based polymers but also expanded the pillararene applications about cation sensing/ adsorption/removal. Thus, this good example might stimulate wide interest of scientists for further development of new pillararene-based polymers. We also expect that our research will help the environment and industry.

\section{Conflicts of interest}

There are no conflicts to declare.

\section{Acknowledgements}

This work was supported by the National Natural Science Foundation of China (NSFC) (No. 21662031; 21661028; 21574104; 21262032) and the Program for Changjiang Scholars and Innovative Research Team in University of Ministry of Education of China (IRT 15R56).

\section{Notes and references}

1 R. P. Schwarzenbach, B. I. Escher, K. Fenner, T. B. Hofstetter, C. A. Johnson, U. von Gunten and B. Wehrli, Science, 2006, 313, 1072.

2 (a) L. You, D. Zha and E. V. Anslyn, Chem. Rev., 2015, 115, 7840; (b) M. Vendrell, D. Zhai, J. C. Er and Y.-T. Chang, Chem. Rev., 2012, 112, 4391; (c) L. E. Kreno, K. Leong, O. K. Farha, M. Allendorf, R. P. Van Duyne and J. T. Hupp, Chem. Rev., 2012, 112, 1105; (d) J. H. Jung, J. H. Lee and S. Shinkai, Chem. Soc. Rev., 2011, 40, 4464; (e) N. Dave, M. Y. Chan, P.-J. J. Huang, B. D. Smith and J. Liu, J. Am. Chem. Soc., 2010, 132, 12668.

3 (a) K. P. Carter, A. M. Young and A. E. Palmer, Chem. Rev., 2014, 114, 4564; (b) X. Li, X. Gao, W. Shi and H. Ma, Chem. Rev., 2014, 114, 590; (c) H. N. Kim, W. X. Ren, J. S. Kim and J. Yoon, Chem. Soc. Rev., 2012, 41, 3210; (d) J. Du, M. Hu, J. Fan and X. Peng, Chem. Soc. Rev., 2012, 41, 4511; (e) D. T. Quang and J. S. Kim, Chem. Rev., 2010, 110, 6280.

4 (a) Z. Wu and D. Zhao, Chem. Commun., 2011, 47, 3332; (b) X. Feng, G. E. Fryxell, L.-Q. Wang, A. Y. Kim, J. Liu and K. M. Kemner, Science, 1997, 276, 923.

5 (a) A. P. Esser-Kahn, A. T. Iavarone and M. B. Francis, J. Am. Chem. Soc., 2008, 130, 15820; (b) Y. Oh, C. D. Morris and M. G. Kanatzidis, J. Am. Chem. Soc., 2012, 134, 14604.

6 M. Khajeh, S. Laurent and K. Dastafkan, Chem. Rev., 2013, 113, 7728.
7 (a) K.-K. Yee, N. Reimer, J. Liu, S.-Y. Cheng, S.-M. Yiu, J. Weber, N. Stock and Z. Xu, J. Am. Chem. Soc., 2013, 135, 7795; (b) C. W. Abney, J. C. Gilhula, K. Lu and W. Lin, Adv. Mater., 2014, 26, 7993; (c) Q.-R. Fang, D.-Q. Yuan, J. Sculley, J.-R. Li, Z.-B. Han and H.-C. Zhou, Inorg. Chem., 2010, 49, 11637.

8 (a) T. Ogoshi, S. Kanai, S. Fujinami, T. Yamagishi and Y. Nakamoto, J. Am. Chem. Soc., 2008, 130, 5022; (b) D. Cao, Y. Kou, J. Liang, Z. Chen, L. Wang and H. Meier, Angew. Chem., Int. Ed., 2009, 48, 9721; (c) M. Xue, Y. Yang, X. Chi, Z. Zhang and F. Huang, Acc. Chem. Res., 2012, 45, 1294; (d) T. Ogoshi, T. Yamagishi and Y. Nakamoto, Chem. Rev., 2016, 116, 7937.

9 (a) Z. Zhang, C. Han, G. Yu and F. Huang, Chem. Sci., 2012, 3, 3026; (b) X.-B. Hu, L. Chen, W. Si, Y. Yu and J.-L. Hou, Chem. Commun., 2011, 47, 4694; (c) N. L. Strutt, R. S. Forgan, J. M. Spruell, Y. Y. Botros and J. F. Stoddart, J. Am. Chem. Soc., 2011, 133, 5668; (d) X.-Y. Hu, X. Wu, Q. Duan, T. Xiao, C. Lin and L. Wang, Org. Lett., 2012, 14, 4826; (e) T.-B. Wei, J.-F. Chen, X.-B. Cheng, H. Li, B.-B. Han, H. Yao, Y.-M. Zhang and Q. Lin, Polym. Chem., 2017, 8, 2005; (f) Y. Chen, M. He, B. Li, L. Wang, H. Meier and D. Cao, RSC Adv., 2013, 3, 21405; (g) Y. Sun, W. Fu, C. Chen, J. Wang and Y. Yao, Chem. Commun., 2017, 53, 3725.

10 (a) W. Cheng, H. Tang, R. Wang, L. Wang, H. Meier and D. Cao, Chem. Commun., 2016, 52, 8075; (b) Y. Cao, X. Hu, Y. Li, X. Zou, S. Xiong, C. Lin, Y. Shen and L. Wang, J. Am. Chem. Soc., 2014, 136, 10762; (c) X. Chi, X. Ji, D. Xia and F. Huang, J. Am. Chem. Soc., 2015, 137, 1440; (d) X. Wang, K. Han, J. Li, X. Jia and C. Li, Polym. Chem., 2013, 4, 3998; (e) W.-B. Hu, W.-J. Hu, X.-L. Zhao, Y. A. Liu, J.-S. Li, B. Jiang and K. Wen, Chem. Commun., 2015, 51, 13882; $(f)$ K. Wang, C.-Y. Wang, Y. Zhang, S. X.-A. Zhang, B. Yang and Y.-W. Yang, Chem. Commun., 2014, 50, 9458.

11 (a) Y. Yao, X. Chi, Y. Zhou and F. Huang, Chem. Sci., 2014, 5, 2778; (b) B. Shi, K. Jie, Y. Zhou, D. Xia and Y. Yao, Chem. Commun., 2015, 51, 4503; (c) T.-B. Wei, J.-F. Chen, X.-B. Cheng, H. Li, B.-B. Han, Y.-M. Zhang, H. Yao and Q. Lin, Org. Chem. Front., 2017, 4, 210.

12 (a) F. Zhang, J. Ma, Y. Sun, I. Boussouar, D. Tian, H. Li and L. Jiang, Chem. Sci., 2016, 7, 3227; (b) X. Cheng, H. Li, F. Zheng, Q. Lin, Y. Zhang, H. Yao and T. Wei, Dyes Pigm., 2016, 127, 59; (c) Y. Fang, X. Yuan, L. Wu, Z. Peng, W. Feng, N. Liu, D. Xu, S. Li, A. Sengupta, P. Mohapatra and L. Yuan, Chem. Commun., 2015, 51, 4263.

13 (a) P. Wei, D. Li, B. Shi, Q. Wang and F. Huang, Chem. Commun., 2015, 51, 15169; (b) T.-B. Wei, X.-B. Cheng, H. Li, F. Zheng, Q. Lin, H. Yao and Y.-M. Zhang, RSC Adv., 2016, 6, 20987; (c) T.-B. Wei, J.-F. Chen, X.-B. Cheng, H. Li, Q. Lin, H. Yao and Y.-M. Zhang, $R S C A d v ., 2016$, 6, 65898; (d) J.-F. Chen, X.-B. Cheng, H. Li, Q. Lin, H. Yao, Y.-M. Zhang and T.-B. Wei, New J. Chem., 2017, 41, 2148.

14 (a) A. Kraft, A. C. Grimsdale and A. B. Holmes, Angew. Chem., Int. Ed., 1998, 37, 402; (b) U. H. F. Bunz, Chem. Rev., 2000, 100, 1605.

15 (a) D. T. McQuade, A. E. Pullen and T. M. Swager, Chem. Rev., 2000, 100, 2537; (b) C. Zhu, L. Liu, Q. Yang, F. Lv and 
S. Wang, Chem. Rev., 2012, 112, 4687; (c) A. H. Hoang and M. Leclerc, J. Am. Chem. Soc., 2003, 125, 4412; (d) M. Vetrichelvan, R. Nagarajan and S. Valiyaveettil, Macromolecules, 2006, 39, 8303.

16 (a) X. Gong, M. R. Robinson, J. C. Ostrowski, D. Moses, G. C. Bazan and A. J. Heeger, Adv. Mater., 2002, 14, 581; (b) G. Yu, J. Gao, J. C. Hummelen, F. Wudl and A. J. Heeger, Science, 1995, 270, 1789.

17 (a) Y. Ma, L. Chen, C. Li and K. Müllen, Chem. Commun., 2016, 52, 6662; (b) S. Sun, X.-Y. Hu, D. Chen, J. Shi,
Y. Dong, C. Lin, Y. Pan and L. Wang, Polym. Chem., 2013, 4, 2224.

18 (a) Q. Lin, P.-P. Mao, L. Liu, J. Liu, Y.-M. Zhang, H. Yao and T.-B. Wei, RSC Adv., 2017, 7, 11206; (b) J.-F. Chen, X. Liu, J.-F. Ma, B.-B. Han, J.-D. Ding, Q. Lin, H. Yao, Y.-M. Zhang and T.-B. Wei, Soft Matter, 2017, 13, 5214.

19 (a) D. Wu, W. Huang, Z. Lin, C. Duan, C. He, S. Wu and D. Wang, Inorg. Chem., 2008, 47, 7190; (b) Y. Zhou, C.-Y. Zhu, X.-S. Gao, X.-Y. You and C. Yao, Org. Lett., 2010, 12, 2566; (c) D. M. Findlay and R. A. N. McLean, Environ. Sci. Technol., 1981, 15, 1388. 